\title{
Global Warming: Real or Feigned Threat to Humanity
}

\author{
Mario C Nierras \\ Faculty of Agriculture, Naval State University-Biliran Campus, Philippines
}

Submission: December 11, 2017; Published: February 05, 2018

"Corresponding author: Mario C Nierras, Faculty of Agriculture, Naval State University-Biliran Campus, Biliran, Biliran Province, Philippines, Email: marionierras@gmail.com

\begin{abstract}
The controversial and prevailing issue of global warming (GW) and/or climate change (CC) poses sizable apprehensions among human populations worldwide. Some less-informed people think that the issue of GW and CC are only imaginary, nonsense simple matter. The truth is that GW is a real occurrence which has a direct or indirect effect to CC and human survival. Eventually, this global phenomenon may determine the fate of humans to exist as organisms in this only living planet. And based on empirical physico-social observations, CC is a valid threat both to one's internal and external communities. Despite of these on-going realities, it is believed that something could still be constructively done to rehabilitate the condition of our ailing environment. The time is not yet too late for us to respond to the pressing demand to restore our nature. However, continual apathy and dispiritedness to the crucial call to revive our ecosystem brought about by GW and CC, could worsen and become irreversible threat to the perpetuation of humanity. Thus, the concerted efforts of all inhabitants of every society in the world are a critically persisting necessity. If we want human species to live through thousands of decades of millennia, now is the opportune time to act sincerely and selflessly for the biotic milieu.
\end{abstract}

Keywords : Altruism; Atmospheric disturbance; Biota; Ecology; Environmental alteration; Greenhouse gases

Abbreviations : GW: Global Warming; CC: Climate Change; GHGs: Greenhouse Gases; $\mathrm{CO}_{2}$ : Carbon Dioxide; $\mathrm{CH}_{4}$ : Methane; $\mathrm{N}_{2} \mathrm{O}$ : Nitrous Oxide

\section{Introduction}

To the layman, GW may be regarded similar or the same as CC. To them they are nothing but some normal physical disturbances or variations in the atmospheric cycle. But literatures say that GW is the rise in the average global surface temperature. It is caused primarily by the build-up of human-produced greenhouse gases (GHGs), mostly carbon dioxide $\left(\mathrm{CO}_{2}\right)$ and methane $\left(\mathrm{CH}_{4}\right)$. These gases trap heat in the lower levels of the atmosphere. While CC refers to the broader set of changes that go along with GW. In other words, CC is an after effect of GW. These alterations include weather patterns, the lands, the oceans, the ice and snow, and ecosystems (Epa.gov). One reality is that to rehabilitate nature is very tedious and challenging.

Climate change is the biggest health threat of the $21^{\text {st }}$ century. It is posited that the effects of CC on human health will affect most populations and will put the lives and wellbeing of billions of people at increased risk. This is so because other inhabitants of this planet simply do not care about environmental conservation. The rises on the Earth's average surface temperatures are likely to go beyond the safe threshold of $2{ }^{\circ} \mathrm{C}$ above preindustrial average temperature. Today, many people knew that the accumulation of GHGs particularly $\mathrm{CO}_{2}$ are the ones responsible for the increase in global temperature. This carbon overload has been said to be mainly due to the burning of fossil fuels like coal, oil, and gas. The problem is further aggravated when we keep on cutting down trees and burning forests. Though there are other gases that contribute to increased environmental temperature like $\mathrm{CH}_{4}$ and nitrous oxide $\left(\mathrm{N}_{2} \mathrm{O}\right)$, they are of secondary importance. Due to human activities, the concentrations of $\mathrm{CO}_{2}$ in the atmosphere keep on increasing. Thus, it stays longer in the atmosphere than the other major heat-trapping gases (Wikipedia.org).

On the other hand, it is also worth knowing that should all of the energy emitted from the Earth's surface escaped into space, the Earth would be too cold to sustain human life. Such that heat-trapping gases serve as a blanket surrounding the Earth and keeps its temperatures within a range that enables life to thrive on the planet. Unfortunately, these gases especially $\mathrm{CO}_{2}$, are accumulating in the atmosphere at increasing concentrations due to man-intervened activities. Thus, the atmosphere's insulating blanket is getting too thick that overheats the Earth because less energy (heat) escapes out into space [1].

Bringing down the temperature of the Earth's atmosphere to optimal level goes with the question of what is the proper thing to be done. As mentioned, the number one cause of $\mathrm{CO}_{2}$ accumulation in the atmosphere that led to the increase in global 
temperature is the burning of fossil fuels. But sad to note that even agriculture (especially livestock production) also accounts about one-fourth of global GHG emissions [2]. This means that the effects of producing red meat from $\mathrm{CH}_{4}$-producing ruminants (e.g. cattle, sheep, and goats) are so great. Some radical thinkers even proposed that production of these animal protein sources should be curtailed in order to get rid of further GHG emissions. This paper aimed to present multifaceted issues and concerns on GW and CC to let global inhabitants appreciate its necessity.

\section{Discussion of Issues}

\section{Effects of CC on key environs and sectors}

Terrestrial: Chakraborty \& Newton [3] posited that global food production must increase by $50 \%$ to meet the projected demand of the world's population by 2050 . The authors claimed that meeting this very difficult challenge will be made even more complicatedly tough if CC would melt portions of the Himalayan glaciers to affect $25 \%$ of world cereal production in Asia.

Geological features of the Earth reminds us that roughly only $25 \%$ of the total global space is covered by land, the rest being wrapped with different forms of water bodies. And sad to say that out of the $25 \%$ land mass only $10 \%$ or less is actually considered potential agricultural lands [4]. Realistically, this $10 \%$ remaining potential agricultural lands are even decreasing time after time due to continued human habitations and land-use conversions.

On the other hand, Jetz et al. [5] worriedly emphasized that over the past few decades, land-use and CC have led to substantial range contractions and species extinctions. That even under environmentally benign scenarios, it is estimated that at least 400 species are projected to suffer $>50 \%$ range reductions by the year 2050, and over 900 by the year 2100. It means that CC will severely affect biodiversity in the near future. Root et al. pointed out that over the past 100 years, the average global temperature has increased by approximately $0.6{ }^{\circ} \mathrm{C}$ and is projected to continue to rise at a rapid rate. While land-use change in tropical countries may further lead to yet greater species losses.

Aerial: The above-ground ecosystem is an equally-important environment to give attention to. An article in Jenkinson et al. [6] say that one effect of GW will be to accelerate the decomposition of soil organic matter thus releasing $\mathrm{CO}_{2}$ to the atmosphere which will boost the warming trend. Relatedly, Cox et al. averred that continued increase in the atmospheric concentration of $\mathrm{CO}_{2}$ due to anthropogenic emissions is predicted to lead to significant changes in climate. They say that about half of the current releases are being absorbed by the ocean and land ecosystems. However, they advanced that this absorption is sensitive to climate and atmospheric $\mathrm{CO}_{2}$ concentrations, creating a feedback loop. In their three-dimensional carbon-climate model, it indicates that carbon-cycle feedbacks could significantly accelerate CC over the twenty-first century. They claimed that under a "business as usual" scenario, the terrestrial biosphere acts as an overall carbon sink until about 2050, but turns into a source thereafter.
Marine: Carpenter et al. [7] in their assessment of reefbuilding corals showed that of the 704 species that could be assigned conservation status, $32.8 \%$ are in categories with elevated risks of extinction. The decreases in abundance were associated with bleaching and diseases caused by increased sea surface temperatures. Results indicate that such extinction risks have been further aggravated by local-scale anthropogenic disturbances. The above findings was also backed up in Guldberg [8], claiming that sea temperatures in many tropical regions have increased by almost $1{ }^{\circ} \mathrm{C}$ over the past 100 years, and are currently increasing at $\sim 1-2{ }^{\circ} \mathrm{C}$ per century. It was asserted that increased sea temperatures result to coral bleaching. Coral bleaching occurs when the thermal tolerance of corals and their photosynthetic symbionts (zooxanthellae) is exceeded.

Similarly in an article, Dudgeon et al. [9] pointed out that fresh waters are also experiencing declines in biodiversity. They say that this fall off is far greater than those in the most affected terrestrial ecosystems. It was further articulated that if trends in human demands for water remain unaltered and species losses continue at current rates, the opportunity to conserve much of the remaining biodiversity in fresh water will vanish even sooner. Turner [10] accentuated that CC is the culprit that poses profound, direct, and well-documented threats to biodiversity. It mentioned that significant fraction of Earth's species is at risk of extinction due to changing precipitation and temperature regimes, rising and acidifying oceans.

Human Health: Myers \& Patz [11] claimed that large-scale anthropogenic changes to the natural environment, including land-use change, CC, and the deterioration of ecosystem services, are all accelerating. They stressed that these changes are interacting to generate five major emerging public health threats that endanger the health and welfare of people. These risks include increasing exposure to infectious diseases, water scarcity, food scarcity, natural disasters, and population displacement. Taken together, they may represent the greatest public health challenge humanity has faced. Additionally, Pounds et al. [12] declared that as the Earth warms, many species are likely to disappear because of changing disease dynamics. Their study showed that recent mass extinction associated with pathogen outbreaks is tied to GW. Hence, with CC promoting infectious diseases and eroding biodiversity, the urgency of reducing GHG concentrations is inexcusable.

\section{Active role or participation enjoined from}

One's self: More than anything else, the great crusade needed to arrest these tremendous ecological enigma need to come from within an individual. No amount of good programs and excellent plans would be useful in solving these global-environmental atrocities if there is no active participation of every citizenry. Such that it is very essential that proper and true understanding of the real score with respect to these global issues need to be understood and internalized by all people in the world. But, this thing is easier said than done because to let a person understand 
and appreciate by heart and mind this environment-restoration campaign is very difficult. To let an individual realize the imperativeness of this crucial issue would take so much time and patience. Nevertheless, it is believed that proper education and instilling of the right value system to oneself is very fundamental in this pursuit (Garvey, 2008).

Family: The family is popularly called as the basic unit of every society. Everyone's first informal education clearly comes from the home. It is where the foundation of the psycho-social orientation of a person is rooted [13,14]. An effective and influential element of one's external actions essentially comes from his own family. Necessarily, a strong nation means one with a firm and well-valued families. Well-valued families produce well-principled persons. They are the ones who could easily understand and responsively adopt sound practices for the good of the environment and for the welfare of the people.

Academes: Colleges and universities whether public or private have expected significant contribution for initiating awareness and desirable practices that are favourable to mitigating the ill effects of CC. The schools have the greatest reach to the masses because almost all parts of any country in the world today have been provided with learning institutions across levels. A common objective should be faithfully adopted among the academes seeing to it that environmental protection should be a key subject area for learning. An agenda promoting the use of eco-friendly organisms like Rhizobium and the utilization of mulching materials in crop production may be a favourable start $[15,16]$.

Developing a desirable personal attitude and right value system of an individual seems to be the most difficult aspect to be changed/adopted in one's behaviour $[17,18]$. But this matter should be treated by the academes as a tough but remediable challenge for the sake of human perpetuation. Losing hope and surrendering to this greatest test of all time would mean the downfall and gradual annihilation of humanity.

\section{National \& Local Government Units (NLGUs)}

One way in which a country may show its concern in rehabilitating nature is to unreservedly participate into such pacts as the Paris Agreement and similar accord. This understanding which took effect on 4 November 2016 stipulates to limit GW to no more than $1.5^{\circ} \mathrm{C}$ above pre-industrial levels [19-21]. It required the Parties to submit their Intended Nationally Determined Contributions (INDCs). The signatories also agreed to come together every five years to report on their emissions and implementations efforts. Correspondingly, attaining the purposes and aspirations of a worldwide covenant would not likely succeed without the active participation of wellinformed leaders of local communities. The kind of leadership that all societies necessitate to possess is proactivity. The handson partaking of local leaders and their constituents of global activities applied in their own districts are indispensable thing in arresting GW. Solving the gigantic problem of CC must appeal the active involvement of all members of every community. Thus, the committed participation of human societies led by their respective frontrunners are specially needed in this extraordinary difficult endeavour [22-25].

\section{Non-Government Organizations (NGOs)}

The idea that NGOs incorporate in their general objective a plan of action for the protection and/or rehabilitation of the environment is remarkably laudable. Being part of the vast surroundings, all types of NGOs need to take active part in arresting or mitigating the ill-effects of GW and CC. These efforts may be done by requesting them or through their own initiative find appropriate solutions to recuperate Mother Nature. Top management may issue formal declaration to their constituents to perform or practice eco-friendly tasks. In the case of religious NGOs, continuously supporting environment protection drive both in word and indeed are some of the most practical instruments they may use for evangelizing their members. In short, ecosystem protection should be the concern of everyone and may not be left only to the environmentalists or to the ecofriendly groups.

\section{Conclusion}

Being aware of the intricacies and ill-effects of GW/ $\mathrm{CC}$ is not enough. Exceedingly more important is to do our part conscientiously and scrupulously. If we fail to perform our personal-civic obligations today, the great misery goes to the posterity. Regaining the good condition of our ailing environment requires a slow and tedious process. But, it is posited that there still goes a thousand ways to bring back the liability of our planet. Today is the exact time to act in rebuilding our unwell environment. Tomorrow might be too late already. There appears to have no swift way nor a magical means for restoring our ecosystem's fitness for the biota. Working together by all sectors towards a common goal in saving Mother Earth is an uncompromising necessity.

In essence and without directly or indirectly imputing a blame on anyone, it is the responsibility of the present generation to do all means to protect or revive our ecosystem. Pointing out fingers as to who is to be condemned would bring no good to us and would just waste our resources. Instead, we should use our limited time to work together in unity to attain our common purpose to arrest this global menace.

\section{Recommendation}

The following ways may be useful in helping out rebuild our deteriorating environment:

a. Encouraging all world leaders to devotedly participate in the crusade to revive nature such as signing the famous Paris Agreement on CC;

b. Designing and faithfully implementing by all countries of programs or activities that sustainably require the active 
participation of every inhabitant regardless of location, race, and nationality;

c. Assessing by every country of all their potential GHG contributors and finding out effective ways of reducing or stopping the continual release of those harmful gases;

d. Participating in the massive replanting of GHG arresters (trees) in all areas especially in the denuded forest lands;

e. Effectively restricting the cutting down of trees worldwide; and

f. Incorporating a subject on "Environmental Awareness \& Protection" in the curricula in all school levels worldwide.

\section{References}

1. US Dept of Energy, Oak Ridge, Tenn, USA (2017) Why does $\mathrm{CO}_{2}$ get most of the attention when there are so many other heat-trapping gases (greenhouse gases)?

2. McMichael, Anthony J (2013) Globalization, Climate Change, and Human Health. The New England Journal of Medicine 368: 1335-1343.

3. Chakraborty S, Newton AC (2011) Climate Change, Plant Diseases and Food Security: An Overview. Climate Change and Plant Diseases 60(1): 2-14.

4. Brady N, Weil RR (1999) The Nature and Properties of Soils. (12 ${ }^{\text {th }}$ edn), McMillan Publishing Co. Inc., USA.

5. Walter J, Wilcove DS, Dobson AP (2007) Projected Impacts of Climate and Land-Use Change on the Global Diversity of Birds.

6. Jenkinson DS, Adams DE, Wild A (1991) Model Estimates of $\mathrm{CO}_{2}$ Emissions from Soil in Response to Global Warming. Nature 351: 304306.

7. Kent EC, Abrar M, Aeby G, Aronson RB, Banks S, et al. (2008) One-Third of Reef-Building Corals Face Elevated Extinction Risk from Climate Change and Local Impacts. Science Journal 321(5888): 560-563.

8. Hoegh GO (1999) Climate Change, Coral Bleaching and the Future of the World's Coral Reefs. Marine and Freshwater Research 50(8): 839866.

9. David D, Arthington AH, Gessner MO, Kawabata ZI, Knowler DJ, et al. (2005) Freshwater Biodiversity: Importance, Threats, Status and Conservation Challenges. Biological Reviews 81(2): 163-182.
10. Will TR (2010) Climate Change: Helping Nature Survive the Human Response. Journal of the Society for Conservation Biology 3(5): 304312.

11. Samuel SM, Jonathan AP (2009) Emerging Threats to Human Health from Global Environmental Change. Annual Review of Environment and Resources 34: 223-252.

12. Alan PJ, Bustamante R, Coloma LA, Consuegra JA, Michael PLF, et al. (2006) Widespread Amphibian Extinctions from Epidemic Disease Driven by Global Warming. Nature 439: 161-167.

13. Anthony C, Abbas M, Allen A, Ball S, Bell S, et al. (2009) Managing the Health Effects of Climate Change. Lancet \& University College London Institute for Global Health Commission 373(9676): 1693-1733.

14. Delaibatiki SN (2014) Family, the Basic Unit of Society.

15. Mario NC (2014) Rhizobium Inoculation as Bio-organic Substitute for Synthetic Nitrogen Fertilization in Peanut. Journal of Society \& Technology 4: 25-30.

16. Mario CN (2015) Effect of Basal Density of Mulched Materials on the Growth and Fruiting Performance of Table Banana (Latundan var.). Asia-Pacific Journal of Multidisciplinary 3(5).

17. Katrin P (2012) Understanding Behavior Change. James Hutton Institute, UK.

18. Jessie $S$ (2011) The Stages of Change.

19. Mike H (2016) $1.5^{\circ} \mathrm{C}$ and Climate Research after the Paris Agreement Nature 6: 222-224.

20. Rajamani L (2016) Ambition and Differentiation in the 2015 Paris Agreement: Interpretative Possibilities and underlying Politics. International \& Comparative Law Quarterly 65(2): 1-25.Top of Form

21. Joeri R, Elzen M, Höhne N, Fransen T, Fekete H, et al. (2016) Paris Agreement climate proposals need a boost to keep warming well below $2{ }^{\circ} \mathrm{C}$. Nature 534: 631-639.

22. Allan CC (1999) The Family as the Fundamental Unit of Society. World Family Forum 1999.

23. Peter MC, Betts RA, Jones CD, Spall SA, Totterdell II (2000) Acceleration of Global Warming Due to Carbon-Cycle Feedbacks in a Coupled Climate Model. Nature Int Weekly Jour of Science Nature 408(6809): 184-187.

24. James G (2008) The Ethics of Climate Change: Right and Wrong in a Warming World. Bloomsbury Publishing, London, UK.

25. Terry RL, Price JT, Hall KR, Schneider SH, Rosenzweig C, et al. (2003) Fingerprints of Global Warming on Wild Animals and Plants. Nature 421: 57-60.

\author{
Your next submission with Juniper Publishers \\ will reach you the below assets \\ - Quality Editorial service \\ - Swift Peer Review \\ - Reprints availability \\ - Manuscript Podcast for convenient understanding \\ - Global attainment for your research \\ - Manuscript accessibility in different formats \\ ( Pdf, E-pub, Full Text, Audio) \\ - Unceasing customer service
}

- E-prints Service

Track the below URL for one-step submission

https://juniperpublishers.com/online-submission.php 